\title{
Engineering Pedagogy as the Basis for Effective Teaching Competencies of Engineering Faculty
}

Tiia Rü̈̈tmann - PhD in Education, Assoc. Prof., Head of Estonian Centre of Engineering Pedagogy, e-mail: tiia.ruutmann@taltech.ee Tallinn University of Technology, Tallinn, Estonia Address: Ehitajate tee 5, 19086 Tallinn, Estonia

Abstract. The article presents the philosophy and the basics of Engineering Pedagogy Science the key to science-based, effective, interactive and motivating teaching engineering, shaping the ground of teaching competencies of engineering faculty, ensuring relevantly one of the prerequisites of the quality of engineering education in general. The foundational questions shaping the philosophy of Engineering Pedagogy Science, as an analytical ground for effective course design and further course development, based on informed decisions, are presented in this paper. The didactic pentagram and the basic didactical model of Engineering Pedagogy Science are discussed in this paper. Didactical pentagram of Engineering Pedagogy Science forms the ground of the essential pedagogical competencies of engineering faculty along with the speciality competencies, ensuring effective teaching engineering. The basic didactic model of Engineering Pedagogy Science follows the principles of an iterative process, being an effective tool for the design of a study program, curriculum, syllabus, course, or a lecture with the aim of effective teaching engineering. Integrated quadruple instructional model of Engineering Pedagogy Science as the foundation of integrated course design and one of the preconditions of effective teaching and learning is introduced as the basis of expected teaching competencies of engineering faculty. Pedagogical competences of the faculty are becoming more considerable in the quality assessment of higher education. The most effective ground of pedagogical continuing education of engineering faculty is Engineering Pedagogy Science, which offers suitable and relevant didactic models for insurance of effective teaching and learning and integrated course design based on informed decisions, learning analytics, reflection and metacognition.

Keywords: Engineering Pedagogy Science, continuing pedagogical education for faculty, didactic model, effective teaching engineering, integrated quadruple instructional model, pedagogical competencies, course design

Cite as: Rüütmann, T. (2019). Engineering Pedagogy as the Basis for Effective Teaching Competencies of Engineering Faculty. Vysshee obrazovanie $v$ Rossii = Higher Education in Russia. Vol. 28, no. 12, pp. 123-131. (In Russ., abstract in Eng.)

DOI: https://doi.org/10.31992/0869-3617-2019-28-12-123-131

\section{Introduction}

Quality of teaching has become an essential indicator of the quality of higher education worldwide. For decades, the mission of technical universities has been the education of engineering faculty and engineering teachers. For this purpose, there are Engineering Education Development Centers (or Centers of Engineering Pedagogy) at most technical universities.
Majority of university faculty members are interested in improvement of the quality of their teaching, taking account of students' feedback, peer-evaluation, reflection, and teaching portfolio analysis. On the other hand, mentoring and the system of continuing pedagogical education for faculty has become more systematic 
at universities of technology nowadays - it has become an important part of the quality system as a whole. Technical universities require the faculty to undergo engineering pedagogical education before starting with teaching, usually in the range of 6-25 ECTS, depending on the university quality policy.

Contemporary effective teaching engineering assumes not only teaching engineering specialty knowledge and skills, but also the development of students' thinking skills - technical, logical, creative and critical thinking, along with problem solving, collaborative learning, communication, attainment of attitudes and values, support of personality development, which are of great importance. The way our students see the future world depends on how future engineers will be able to solve non-standardized multidisciplinary realworld problems [1]. Engineering Pedagogy Science is a key to science-based, effective and motivating teaching engineering, and builds the ground of teaching competencies of engineering faculty.

\section{Philosophy of Engineering Pedagogy Science}

Contemporary Engineering Pedagogy Science (EPS) is an interdisciplinary discipline of Pedagogy, the scientific basis of which was constituted by Klagenfurt School of Engineering Pedagogy [2]. At present Engineering Pedagogy Science is being developed specifying its methodological status and subject area [3-4].

There has been an immense development in the system of teaching and learning in recent years: proceeding from teacher-centered teaching to learner-centered teaching, and finally up to contemporary learning-centered and interactive teaching. Processes experienced by students, negative and positive emotions, balance between group work and individual work (individual and social learning), efforts and activities, analysis and self-evaluation, success and failure, metacognition and feedback, learning from experiences and mistakes, support the development of students and from the other hand are supported by relevant competencies of engineering faculty.

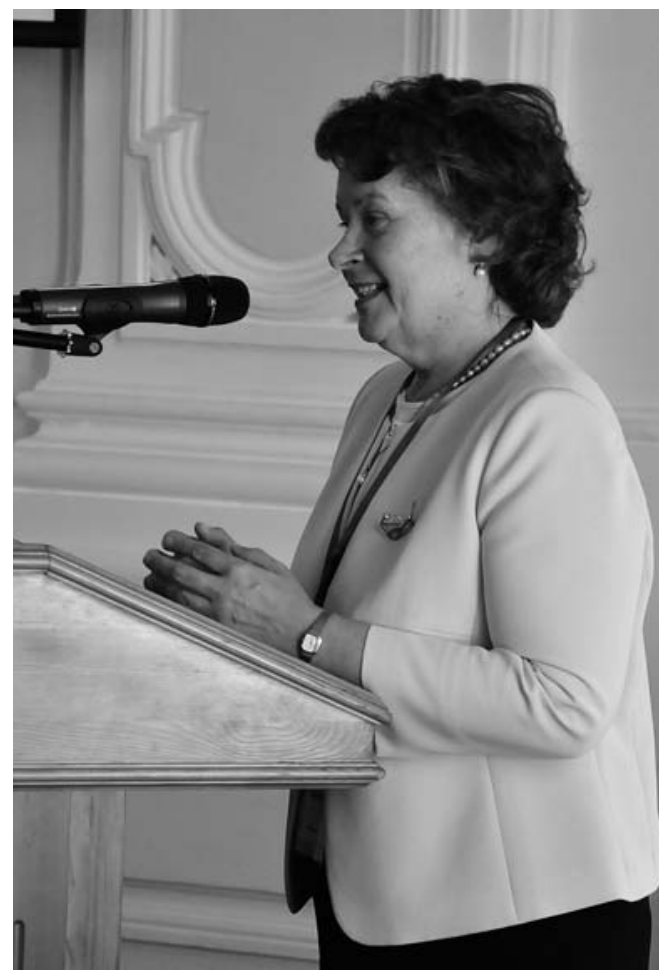

Making mistakes and learning from them have been one of the most important ideas and methods of EPS, based on student-teacher partnership, supported by an interdisciplinary approach and an integrated learning content engineers always learn in an integrated and interdisciplinary way.

Philosophy of EPS relates to the following foundational questions:

- Why we teach?

- How we teach?

- What we teach?

- Whom we teach?

- Who will teach?

- Where we teach?

- When we teach?

- How much should we teach?

- How our students learn?

- How to interact with students?

- How to manage the course?

- How to enhance learning?

- How to motivate students?

- How to develop as educators? 


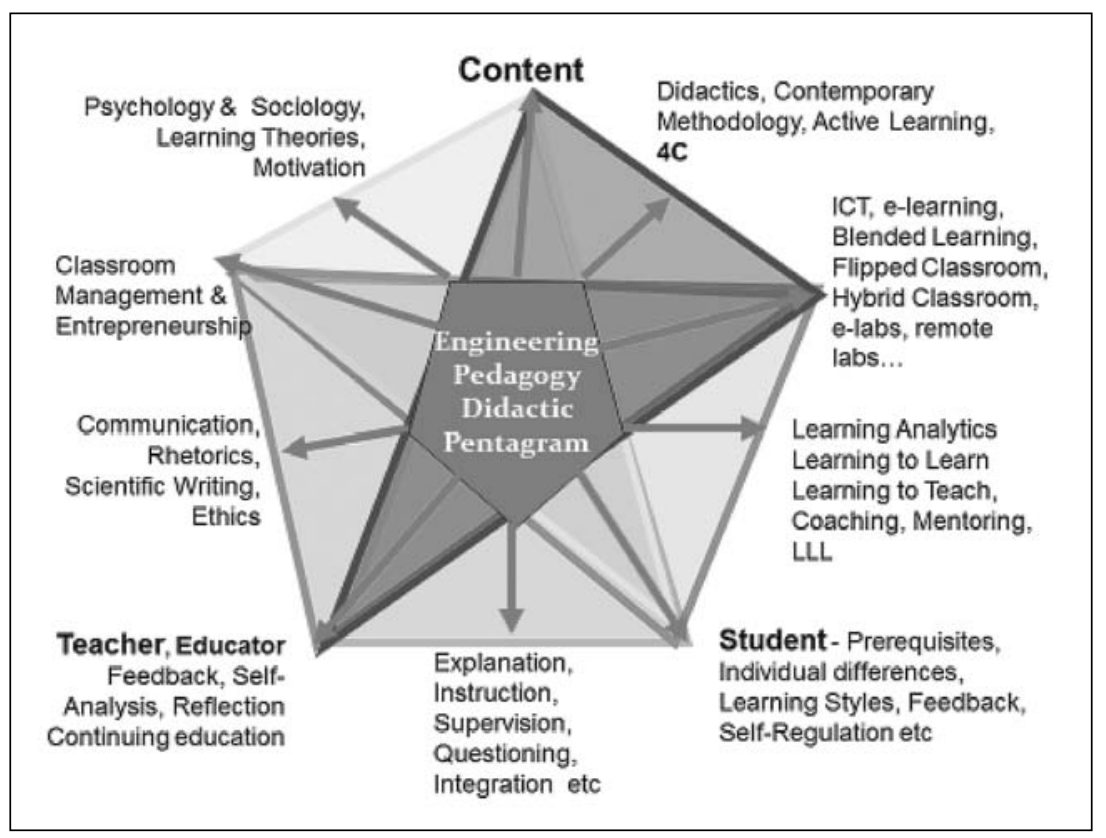

Fig. 1. Didactic Pentagram of EPS [5]

To ensure prerequisites of effective teaching it is important to analyze the relevance of engineering teaching accordingly to the foundational questions introduced above. Foundational questions create an analytical ground for the effective course design and further development, based on informed decisions.

\section{Didactic Pentagram of Engineering Pedagogy Science}

In Engineering Pedagogy Science, effective teaching engineering depends on a number of variables, which form the foundation of EPS Didactic Pentagram (see Fig. 1) designed by T. Rüütmann [5] developed from M. Uljens [6]:

- Instructional goals and learning outcomes for higher level learning;

- Students' psycho-structure (psychology, students' individual differences, learning styles, level of motivation, prior knowledge, self-regulation, feedback, ethics, etc.);

- Instructors' competencies and roles (competencies in specialty and didactics, learning theories, motivation, self-analysis, reflection, life-long learning, feedback, rhetoric, ethics, classroom management skills, entrepreneurship, learning analytics, etc.);

- Course content (learning materials, visual aids, literature, videos, etc.);

- Socio-structure (learning environment, cooperation, teamwork, creativity, critical thinking, collaboration, communication; etc.);

- Teaching technology, media, e-learning (blended learning, distant, remote and e-labs, robotics, flipped classroom and hybrid classroom, drones, virtual and augmented reality, simulations, etc.);

- Teaching methodology, models and strategies (deductive and inductive teaching, active learning, case-analysis, studio learning, engineering design, lab methodology, interactive teaching, PBL, peer-instruction, etc.);

- Assessment and feedback methodologies;

- Analysis and reflection (strengths and weaknesses, analysis of students' feedback, compilation of teaching philosophy statement and teaching portfolio, peer-evaluation, coaching and mentoring, etc.).

According to Figure 1, the so-called "Classic didactic triangle" (Teacher- Students - 


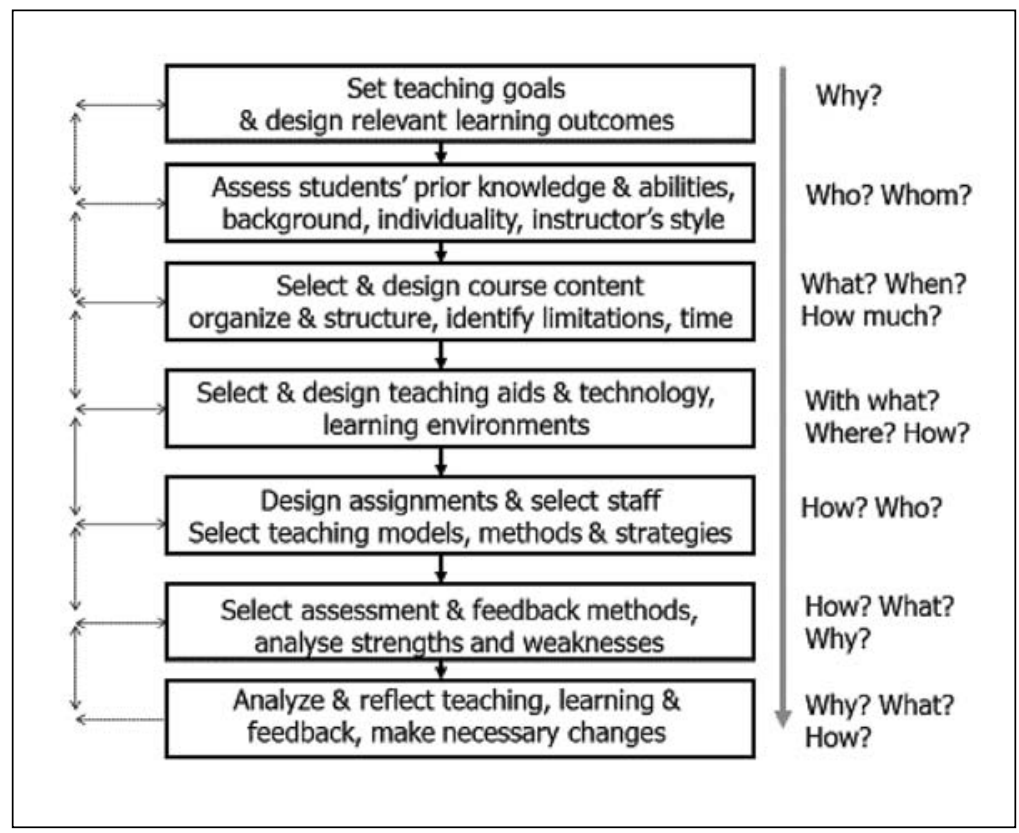

Fig. 2. The Basic Didactic Model of EPS [5]

Course content) based on the grounds of didactics serves as the basis of EPS Didactic Pentagram [5]. Accordingly, a teacher will have to teach students the course content (taking account of students' individual differences and prerequisites) by explaining, supervision, questioning, integration, showing connections, using didactic basics for supporting learning with deep understanding, etc. Additionally, the following triangles support the described basic one in the didactic pentagram [5]:

- Students - Independent learning Classroom management: for independent learning via e-leaning it is essential to teach students to learn, teachers have to learn how to teach via Internet, use learning analytics, participate in coaching and mentoring, learn classroom management and entrepreneurship;

- Teacher- Independent learningCourse content: for supporting classroom learning, individual learning or e-learning, teachers use contemporary methodology, active learning structures, and integration, supporting communication, collaboration, creativity and critical thinking;
- Classroom management- Course content - Students: teachers have to master the basic principles of psychology and sociology, and know learning theories for supporting learning and motivation;

- Teacher - Independent learning - Classroom management: for supporting classroom and independent learning teachers have to master the basics of rhetoric, ethics, supportive communication and scientific writing for compilation of effective learning aids and materials.

The above-discussed Didactic Pentagram of EPS (Fig. 1.) forms the ground of the pedagogical competencies of engineering faculty along with the speciality competencies, ensuring effective teaching and learning engineering.

\section{The Basic Didactic Model} of Engineering Pedagogy Science

Based on cited upon EPS Didactic Pentagram, the Basic Didactic Model of Engineering Pedagogy Science has been designed by A. Melezinek [2] and upgraded by T. Rüütmann [5] (see Fig. 2).

The basic Didactic Model of EPS follows the principles of an iterative process, being an ef- 
fective tool for the design of a study program, curriculum, syllabus, course, or a lecture with the aim of effective teaching engineering. Each step should be analysed in particular relying on the selected suitable didactic models. Possible influence of every further step planned should be analysed taking account of the analysis and decisions of all previous steps [2; 5].

Design of Learning Outcomes. Implementation of the model starts from this first step with the design of learning outcomes and their analysis based on the selected didactic models (e.g. Feisel - Schmitz's Technical Taxonomy [7], Problem-Based Learning Taxonomy [8], Domin's Taxonomy of Laboratory Instruction [9], Bloom's Taxonomy [10], etc.), analysing the level of thinking for supporting of higher level learning. Students have to learn not only the facts and conceptions, but they will also have to implement their knowledge, analyse, evaluate and create, find solutions, build connections, and solve real-life problems, learning from experiences.

Learners' Individual Differences. The second step of the basic model is to take account of learners' individual differences: learning styles, inborn psychological differences (temperament, ability to switch attention, persistence of attention, selfexpression, introvert, extravert, etc.), prior knowledge, learning motivation, self-regulation, communication, etc. [11]. A suitable learning styles model may be selected for the analysis of students' learning styles (Felder - Silverman's Model [12], Kolb's Learning Styles Model [13], Gardner's Model [14], Myers - Briggs' Model [15], etc.).

Course Content. Design relevant course content, learning aids and materials, assignments and select literature accordingly, to support the learners to reach designed learning outcomes.

Teaching Aids and Technology. Select suitable teaching technology, learning environment, classroom or lab, e-learning or blended learning, flipped classroom or hybrid classroom, ICT tools, suitable for the students, course content, and for reaching designed learning outcomes.

Teaching Methods, Models, and Strategies. Select relevant teaching model (build the balance between deductive and inductive teach- ing), consider the fact that traditional (direct/ deductive) teaching gives students systematic knowledge and abstract thinking; inductive (indirect) teaching gives analytical thinking but do not give systematic knowledge. Select a variety of suitable teaching methods, both from direct and indirect teaching model for the design of an effective teaching methodology (interactive lectures, seminars, practical lessons, labs, $\mathrm{PBL}$, projects, active learning structures, studio learning, CDIO [7], simulations, discussions, educational games, engineering design, etc.). Elaborate relevant teaching strategies (clear expectations, questioning, peer-teaching, collaborative learning, visualisation, building connections and relations, analysis and evaluation, critical thinking, conclusions, reflection, metacognition, etc.).

Assessment and Feedback. Select relevant assessment tools for the designed methodology and course content suitable for assessing whether the students have gained the designed learning outcomes. Select relevant feedback models and formative assessment tools. Give constructive and coaching feedback. Ask for students' feedback. Use self-assessment and peer-assessment.

Analysis, Reflection and Metacognition. Analyse students' feedback along with your teaching with the aim of improving teaching and supporting learning with deep understanding. Compile and renew teaching philosophy statement and teaching portfolio. Participate in coaching, mentoring and peer-evaluation. Design your self-development and contribute to life-long learning.

Follow the iterative process, analysing the following indicators:

- What will students have to be able to know/do after your course?

- Are the designed learning outcomes clear and understandable?

- Are the designed learning outcomes assessable?

- How can students prove that they have reached learning outcomes?

- Have you taught (or provided) the material you will assess? 


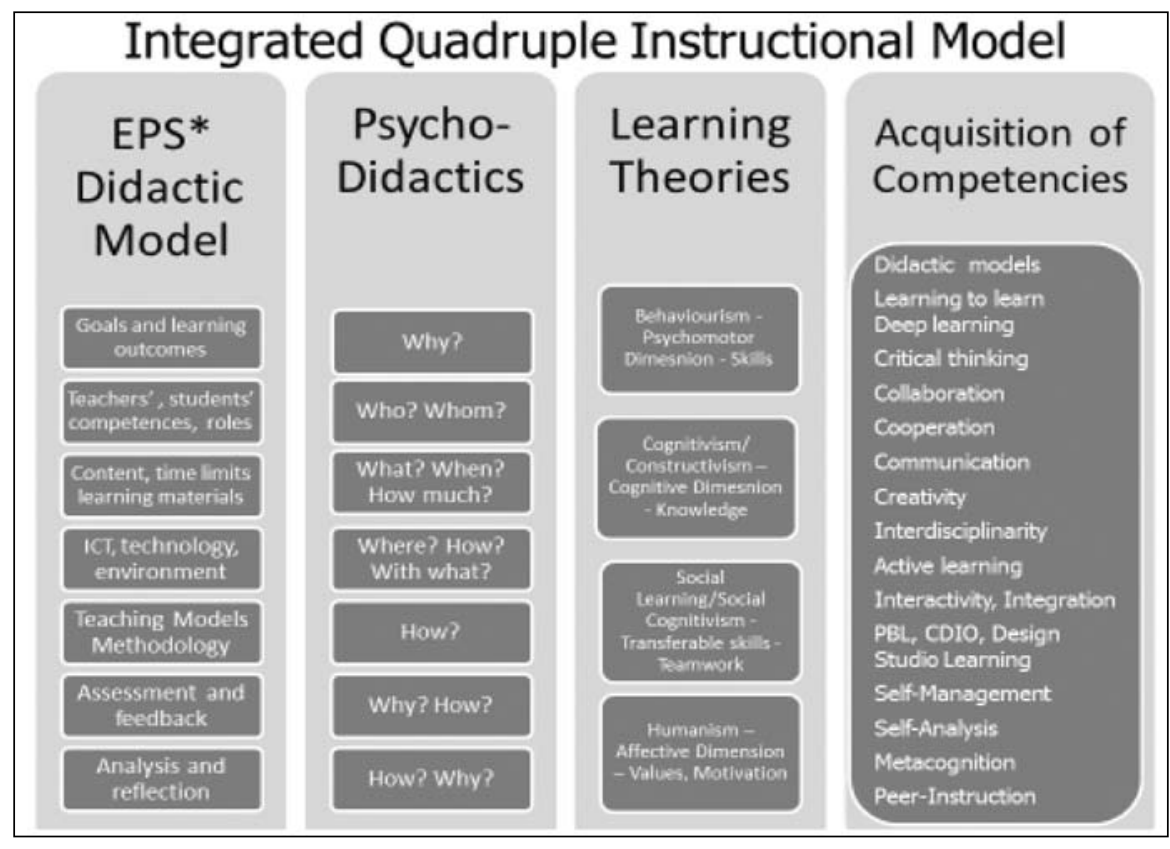

* Engineering Pedagogy Science

Fig. 3. Integrated Quadruple Instructional Model of EPS

- Have you provided multiple of activities for implementation, analysis and evaluation of the course content?

Follow the principles of constructive alignment: align designed learning outcomes, course content, teaching and learning, assessment and feedback, in relation of students' individual differences, teaching technology, ICT tools, and supportive learning environment.

The Basic Didactic Model of EPS guarantees informed decisions for effective course design and the further course development.

\section{Integrated}

\section{Quadruple Instructional Model}

Integrated Quadruple Instructional Model of EPS (see Fig. 3) designed by T. Rüütmann [2] on the ground of:

- The Basic Didactic Model of EPS (Fig. 2);

- Psycho-didactics - science integrating pedagogy and psychology;

- The basic learning theories [16];

- Methods and principles of acquisition of competencies (knowledge, skills and values).
This model integrates the most considerable learning theories for engineering education along with their basic principles [5]:

- Bebaviourism. This learning theory contributes to engineering education with safety regulations and requirements, ergonomics, learning goals and outcomes, course learning guide, timetable, deadlines, rules and regulations, assessment criteria, learning environment, and roles of a learner and instructor. Firstly, behaviourism creates the basis of psychomotor dimension of learning - acquisition of skills. Professional skills should be acquired accurately and according to the specialty requirements.

- Cognitivism/Constructivism. This learning theory creates the basis of the cognitive dimension of learning - acquisition of knowledge. It supports critical and logical thinking, learning with understanding and comprehension, active learning, course design, integration and building connections for construction of knowledge. Experiential learning, creativity, visualisation, memory peculiarities, interdisciplinary learning, processing of information, 
building connections, methodology are all the elements of this learning theory. This theory justifies the need for taking account of students' prior knowledge, individual differences and learning styles for effective teaching and learning.

- Social Learning Theory/Social Constructivism. This theory integrates group processes, group work and teamwork to the process of learning. Social interaction plays a fundamental role in the development of cognition and thinking. This learning theory integrates interaction, discussions, peer-instruction, cooperation, collaboration, communication, developing the process of learning into the meaningful learning for acquisition of social skills.

- Humanism. This learning theory creates the basis of affective dimension of the process of learning - acquisition of values. The theory integrates the principles of motivation, selfanalysis, self-regulation, self-management, selfdevelopment, time management, responsibility, peer-assessment, peer-evaluation, adult education, reflection and metacognition into the process of learning.

It is recommended to design the study programme, course, lecture, etc. taking account of the above-introduced integrated model. The model is a convenient tool for the design of pedagogical courses for engineering faculty continuing education. Integrated Quadruple Instructional Model is the foundation of the integrated course design and precondition of effective teaching - accordingly, it is the basis of effective teaching competencies of engineering faculty.

\section{Conclusions}

The quality of engineering education crucially depends on the specialty and pedagogical competencies of engineering faculty. Pedagogical competences are becoming more considerable in the quality assessment of higher education. The basis of pedagogical education of engineering faculty is Engineering Pedagogy Science, which offers suitable and relevant didactic models for insurance of effective teach- ing and meaningful learning. Integrated Quadruple Instructional Model as the foundation of the integrated course design and precondition of effective teaching may provide grounds for effective teaching competencies of engineering faculty.

\section{References}

1. Zafoschnig, A. (2018). Smart Ideas for Engineers - the Impact of Emerging Technologies on Modern Engineering Education. Vysshee obrazovanie $v$ Rossii = Higher Education in Russia. Vol. 27, no. 6, pp. 66-70.

2. Melezinek, A. (1999). Ingenieurpädagogik Praxis der Vermittlung technischen Wissens, Springer-Verlag, Wien New York, $4^{\text {th }}$ edition.

3. Ivanov, V.G., Sazonova, Z.S., Sapunov, M.B. (2017). Engineering Pedagogy: Facing Typology Challenges. Vysshee obrazovanie $v$ Rossii $=$ Higher Education in Russia. No. 8/9 (215), pp. 32-42. (In Russ., abstract in Eng.)

4. Kubrushko, P.F., Eprikyan, D.O. (2018). Engineering Pedagogy in Vocational Education: Methodological Aspect. Vysshee obrazovanie v Rossii = Higher Education in Russia. Vol. 27, no. 6, pp. 83-87. (In Russ., abstract in Eng.)

5. Rüütmann, T. (2019). Engineering Pedagogy Science as the Contemporary Basis for Effective Teaching of Science, Technology and Engineering. In: Science and Technology Education: Current challenges and possible solutions: Proceedings of the $3^{\text {rd }}$ International Baltic Symposium on Science and Technology Education (BalticSTE2019), Ed. V. Lamanauskas, Šiauliai, Lithuania: Scientia Socialis Press, pp. 187-194.

6. Uljens, M. (Ed). (1997). Didaktik-teori, reflektion och praktik. Studentlitteratur. Lund. $267 \mathrm{p}$.

7. Crawley, E.F., Malmqvist, J., Östlund, S., Brodeur, D.R., Edström, K. (2014). Rethinking Engineering Education. The CDIO Approach. Springer International Publishing. $311 \mathrm{p}$.

8. Hmelo-Silver, C.E. (2004). Problem-Based Learning: What and How Do Students Learn? Educational Psychology Review. Vol. 16, no. 3, September, pp. 235-266.

9. Domin, D.S (1999). A Review of Laboratory Instruction Styles. Journal of Chemical Education. Vol. 76, no. 4, April, pp. 543-547.

10. Krathwohl, D.R. (2002). A Revision of Bloom's Taxonomy: An Overview. Theory Into Practice. Vol. 41, no. 4, autumn, pp. 212-218. 
11. Polyakova, T.Y. (2018). Peculiarities of the Modern Generation of Students and their Influence on the University Foreign Language Training Development. Vestnik Moskovskogo Gosudarstvennogo Lingvisticheskogo Universiteta. Obrazovanie $i$ Pedagogicheskie Nauki = Vestnik of Moscow State Linguistic University Education and Pedagogical Studies. No. 2 (796), pp. 43-54 (In Russ., abstract in Eng.)

12. Felder, R.M., Silverman, L.K. (1988). Learning and Teaching Styles in Engineering Education. Engr. Education. Vol. 78, no. 7, pp. 674-681.

13. Kolb, D.A. (1984). Experiential Learning: Experience as the Source of Learning and Development (Vol. 1). Englewood Cliffs, NJ: Prentice-Hall. 256 p.
14. Gardner, H. (2003). Frames of Mind. The Theory of Multiple Intelligences. New York: Basic Books.

15. Fulton, S. (2016). The Myers-Briggs Type Indicator Handbook - Everything You Need to Know about Myers Briggs type indicator. Emereo Publishing.

16. Ching-Chung Guey, Ying-ying Cheng, Seiji Shibata. (2010). A Triarchal Instruction Model: Integration of Principles from Behaviorism, Cognitivism, and Humanism. Procedia Social and Bebavioral Sciences. No. 9, pp. 105-118.

The paper was submitted 15.10.19 Received after reworking 05.11.19 Accepted for publication 15.11.19

\title{
Инженерная педагогика как основа эффективных педагогических компетенций преподавателей инженерных факультетов
}

\author{
Рюютманн Тийа - доктор философии по педагогике, доцент, заведующая Центром Эстон- \\ ской инженерной педагогики. E-mail: tiia.ruutmann@taltech.ee \\ Таллиннский Технический Университет, Таллинн, Эстония \\ Адрес: Эхитаяте тээ 5, 19086, Тахлинн, Эстония
}

Аннотация. В данной статье представлень философия и основы инженерной педагогики. Они рассматриваются как ключ к научно обоснованному, эффективному, интерактивному и мотивирующему обучению инженерным наукам, формирующему основу для компетенщий преподавателей инженерньх факультетов, обеспечивающему, соответственно, одну из предпосылок качественного инженерного образования в челом. Основополагаючие вопросы философии инженерной педагогики являются аналитической основой для эффективного планирования и дальнейшего развитиякурса при условии обоснованных решений, представленньх в этой статье. В статье обсуждаются дидактическая пентаграмма и базовая дидактическая модель инженерной педагогики. Аидактическая пентаграмма инженерной педагогики является основой базовых педагогических компетениий преподавателей инженерных факультетов наряду со спечиальными компетенчиями, обеспечивающими эффективное преподавание инженерных спечиальностей. Базовая дидактическая модель инженерной педагогики следует приниипам итеративного прочесса, являясь универсальным инструментом для разработки учебной программы, учебного плана, курса или лекции с челью эффрективного обучения инженерным спечиальностям. Реализачия интегрированной четьрёхкомпонентной модели обучения инженерной педагогике как основы дляразработки интегрированного курса, учитьваюшей основные теории обучения, предварительные знания и характеристики студентов, - одно из предварительных условий эффективного обучения и предпосылка для формирования ожидаемьх педагогических компетенчий преподавателей инженерньх факультетов. Педагогчческе компетениии преподавателей приобретают всё большее значение в оченке качества вьсшего инженерного образования. Современный подход к преподаванию предполагает не только обучение студентов инженерным знаниям и умениям в рамках спечиальности, но и развитие $у$ них навьков технического, логчческого, творческого и критического мыпления, а также навьков решения проблем, совместного обучения, общения, достижения ченностей, поддержки 
развития личности, которье все без исключения имеют ключевое значение. Наиболее эфрективной основой для педагогического непрерььного образования преподавателей инженерньхх факультетов является инженерная педагогика - наука, которая предлагает подходящие $и$ актуальнье дидактические модели для эффективного планирования, обучения, а также для комплексного, интегрированного дизайна курса, основанного на осознанньх решениях, аналитике обучения, рефлексии и метапознании.

Ключевые слова: инженернал педагогика, непрерьвное педагогческое образование, педагогчческие компетении преподавателя, дидактическая модель, интегрированная четьрёхкомпонентная модель обучения, разработка учебной программь, дидактическая пентаграмма, дидактическая модель инженерной педагогики

Aля циитированил: Rü̈tmann T. Engineering Pedagogy as the Basis for Effective Teaching Competencies of Engineering Faculty// Высшее образование в России. 2019. Т. 28. № 12. С. 123-131.

DOI: https://doi.org/10.31992/0869-3617-2019-28-12-123-131

Статья поступила в редакиию 15.10.19

После доработки 05.11.19

Принята к публикачии 15.11.19

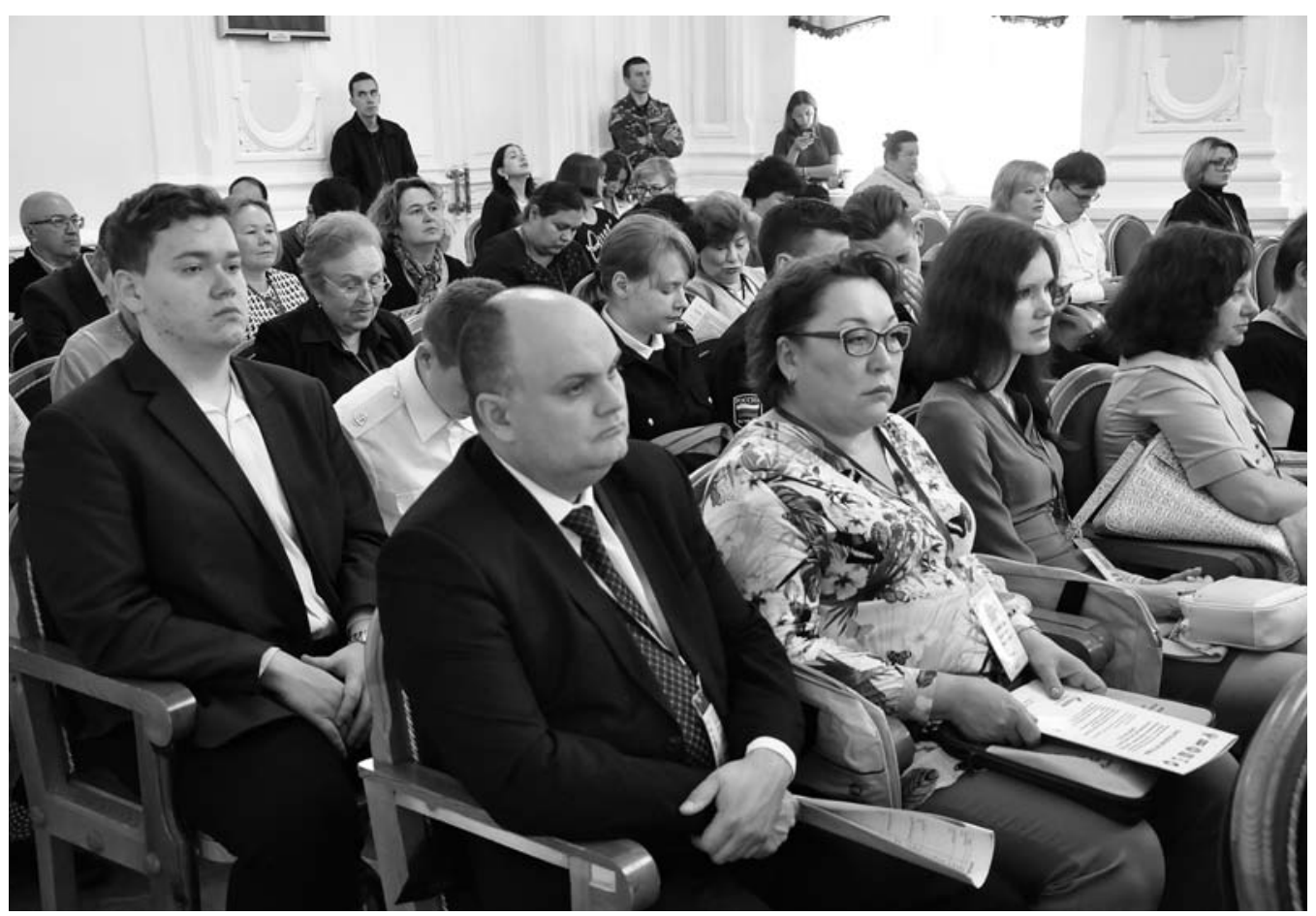

